\title{
Eğitim Fakültesinde Görevli Akademisyenlerin Alternatif Eğitim/Okul Hakkındaki
}

\section{Görüşleri}

\section{Sinan SCHREGLMANN*}

Öz: Bu araştırmanın temel amacı, Türkiye'de eğitim fakültelerinde çalışan akademisyenlerin alternatif eğitim/okullara ilişkin görüşlerini belirlemektir. Bu temel amaç doğrultusunda 2017-2018 eğitim öğretim yılında Türkiye'de yer alan üniversitelerdeki eğitim fakültesinde görevli akademisyenlere e-posta aracılığı ile ulaşılmış ve “Alternatif Eğitim/Okul" konusunda hazırlanan yarı yapılandırılmış yazılı görüşme forumları aracılığı ile veriler toplanmıştır. Araştırmanın çalışma grubunu, Türkiye'de 36 farklı üniversitenin eğitim fakültelerinde görev yapan toplam 93 akademisyenden oluşmuştur. Araştırmanın amacına uygun olarak bu araştırma nitel bir çalışmadır ve veriler betimsel analiz yöntemi ile çözümlenmiştir. Elde edilen bulgulara göre: alternatif eğitim/okul akademisyenler tarafından çok farklı açılardan yorumlanmış olup akademisyenlerin bir kısmı bu konu hakkında hiçbir bilgiye sahip olmadığını belirtirken, diğer bir kısmı ise konuya ilişkin sınırlı kuramsal bilgilerinin olduğunu kabul etmişlerdir. Alternatif eğitim/okul uygulamalarına ilişkin görüşler ise olumlu, olumsuz ve temkinli olacak şekilde üç farklı uçta toplanmıştır. Aynı zamanda alternatif eğitimin/okulların Türkiye'nin kültürüne ve eğitim anlayışına uygun olmadığını, var olan sistem ile ciddi uyuşmazlıkları olduğunu düşünen akademisyenler, alternatif eğitimin/okulların Türkiye'de doğru bir şekilde işlemeyeceğini ifade etmişlerdir. Bununla birlikte eğitim fakültelerinde öğretmen yetiştirme alanında "alternatif eğitim/okullara yönelik" sadece "teorik" değil uygulama anlamında da eğitimler verilmesi olumlu olarak karşılanabilir.

Anahtar Kelimeler: Alternatif Eğitim, Alternatif Okul, Eğitim Fakültesi, Akademisyen Görüşleri, Nitel Araştırma.

\footnotetext{
*Dr. Öğr. Üyesi, Hatay Mustafa Kemal Üniversitesi, Eğitim Fakültesi, Eğitim Bilimleri Bölümü, Email:sinansch@gmail.com Orcid No: 0000-0002-5738-3167
} 


\section{The Views of Academics Working at Education Faculties on Alternative}

\section{Education/Schools}

Abstract: The main objective of this research is determining the views of academics working at education faculties in Turkey on alternative education / schools. In accordance with this basic aim, in the 2017-2018 academic year, academics working at education faculties in universities located in Turkey were reached via e-mail and data were collected through semistructured interview forms designed on the topic named "Alternative Education / School". The participant group was composed of a total of 93 academics working at education faculties from 36 different universities in Turkey. In parallel with the aim of the study, the present research is qualitative and the collected data were analyzed through descriptive statistics. The findings suggested that alternative education/school was evaluated from different aspects, while some of the academics stated that they had no information about this subject, the others accepted that they had limited theoretical information on the subject. The views on alternative education/schools were categorized into three as positive, negative, and cautious. At the same time, the academics who think that alternative education/schools are not fitting to Turkey's culture and understanding of education, there are serious conflicts with the current school system; they stated that alternative education/schools would not be able to function properly. In addition, in the field of teacher training in education faculties, it can be positively welcomed to provide trainings towards "alternative education / schools" not only "theoretically" but also practically.

Keywords: Alternative Education, Alternative School, Faculty of Education, Academician Opinions, Qualitative Research.

\section{Giriş}

Okul: "Her türlü eğitim ve öğretimin toplu olarak yapıldığı bilgi, beceri ve alışkanlıkların belli amaçlara göre düzenli bir biçimde öğretildiği ve kazandırıldığı eğitim kurumu” olarak tanımlanmaktadır (Türk Dil Kurumu, 2011). "Eğitilecek olan bireylere önceden belirlenen amaçlar doğrultusunda yeni davranışlar kazandıran bir sistem” (Adıgüzel, 2006), “yönetim ve öğretim elemanları, öğrenciler ve ilgili başka görevlilerin içinde gerekli eğitim öğretim çalışmalarını sürdürdükleri yapı, çerçeve ya da düzen” (Dravor, 2009), "Planlı bir öğrenme çabası” (Balcı, 2007), "sosyal hayattaki rollere hazırlayan kurum” (Nalçacı \& Bektaş, 2012) gibi farklı tanımlar olmasına rağmen okul; çevre faktörü hesaba katılarak "Bireyin gelişimine etkisi olan genel çevreye karş1lık bilinçli olarak yaratılan özel bir çevre" 
olarak tanımlanmaktadır. Bu çevre genel çevrenin olumsuz etkilerini ortadan kaldırmak, olumlu etkilerini ise pekiştirmek üzere geliştirilmiştir (Balcı, 2007).

Okulların sosyal, politik ve ekonomik görevleri bulunduğu düşünüldüğünde; okulların temel amacı çevrenin sosyal, politik ve ekonomik olumsuz etkilerini ortadan kaldırmak, aynı şekilde çevrenin sosyal, politik ve ekonomik olumlu etkilerini ise pekiştirmektir. Sosyal görevden kasıt çocuğu sosyalleştirmek ve çocuğa kültürü aşılamaktır. Okulun politik görevinden kasıt yetiştirdiği kuşağın devlete olan bağlılığını sağlamak iken ekonomik görevi ise, ekonominin beyin gücü ve insan gücü gereksinimini karşılamaktır (Bursalıoğlu, 2005). Okulların aslında dünü, bugünü ve yarını kapsadığı düşünüldüğünde; okulların bu değerleri korunması ve devam ettirilmesi konusunda ciddi görevleri bulunmaktadır. Okulun bu görevlerine "hem bireysel hem de toplumsal ihtiyaçlar doğrultusunda verdiği eğitimin yanında, toplumun ve ailelerin istemediği kötü alışkanlıkları da dolaylı olarak kazandırdığına” yönelik eleştirilerin artmasından dolayı insanlar zaman zaman farklı arayışlar içerisine girmiştir (Kartal, 2014). Bu durum zamanla "alternatif eğitim/alternatif okul" gibi kavramların da ortaya çıkmasına sebep olmuştur.

Franklin 2002'de alternatif okul kavramını "geleneksel okuldan yapısı farklı olan eğitim programı" anlamında kullanmıştır. Coeyman (2000) ise alternatif okulları "toplumsal sistemin bir parçası olan ve geleneksel akademik çevrelerde başarısız olan öğrencileri destekleyen, geleneksel yaklaşımın haricindeki okullar" olarak tanımlamıştır ve Miller'ın (2006) sınıflandırılmasına göre alternatif okullar (a) Özgürlüğe dayalı öğrenme, (b) Sosyal oluşturmacılık, (c) Eleştirel pedagoji, (d) Ruhsal gelişmecilik, (e) Holistik / integral (bütüncül) model şeklinde kategorilere ayrılmaktadır.

Özgürlüğe dayalı öğrenme kategorisinin felsefeci ve teorisyenleri Leo Tolstoy, Francisco Ferrer, A.S. Neill, Paul Goodman, John Holt, George Dennison, IvanIllich'a göre Öğrenenin otonomisi ve özgürlüğü olabildiğinde az sınırlandırılıp, öğrenme bireyin ihtiyaçları, amaçları ve arzularıyla başlarken yani bireyci bir yaklaşım izlenmektedir. Sosyal oluşturmacılık modeli kategorisinde ise John Dewey, Jean Piaget ve LevVygotsky öğrenmeyi "bir çevredeki insanlar arasında anlamlı bir etkileşim gerektiren, bilerek işbirliğini, araştırmayı ve yaratıcı problem çözmeyi teşvik eden, sosyal bir çaba" olarak tanımlamaktadır (ReggioEmilia, Friends (Quarker) okulları). Eleştirel pedagoji kategorisinde PauloFreire Eğitimin ana amacını "sosyal sorumluluğun ya da toplumun sosyal olarak yeniden yapılandırması ile önemini vurgulamak" olarak tanımlar. Aynı zamanda eleştirel pedagojide merkez bireyde değil toplumdadır (Halk eğitimi). Ruhsal gelişmecilik kategorisinde ise Maria 
Montessori, RudolfSteirner, Hazret InayatKhan gibi Felsefeciler ve teorisyenler İnsan varlığında ruhsal bir boyut olduğu düşüncesini temel aldığından otorite uğruna otoriteye başvurmaz; bunun yerine her çocuğun gizil potansiyellerini desteklemeyi amaçlayan bir yapıyı kurmayı tasarken aynı zamanda özel olarak eğitilmiş ve öz disipline olmuş bir öğretmenin rehberliğinin çocuğun potansiyelini gerçekleştirmek açsından öneminden (WEB, 2019) bahseder (Montessori, Waldorf Okulları). Son olarak Holistik / integral (bütüncül) kategorisinde JidduKrishnamurti, P.R. Sarkar, KenWilber, David Bohm, Alfred North Whitehead, FritjofCapra, AnnaLemkow, ErvinLaszlo, GregoryBateson, David Ray Griffin, Buckminster Fuller gibi felsefeci ve teorisyenler her nesne, fikir ya da canlı varlık, hem kendi içinde bütün, hem de ona anlamını veren sonsuz bir bütünlük serisinin bir parçası olduğunu iddia eder. Aynı zamanda her öğrenme durumuna yanıt vermek için özgürlük ve yapı, bireysellik ve sosyal sorumluluk, ruhsal bilgelik ve kendiliğindenlik arasında denge (İnternet (WEB), 2019) kurulmasının önemli olduğu belirtilir.

Alternatif okulları birbirinden kesin sınırlarla ayırmak her zaman mümkün olmadığından yukarıda bahsedilen kategorilerden herhangi biri altında nitelenen bir okul, diğer modellerin de unsurlarını taşıyabilmektedir (Korkmaz, 2005). Önemli olan standartlaşan okul modeline bir alternatif oluşturmalarıdır. Bu sebeple araştırmamızda akademisyenlerin görüşlerinin daha iyi özümsenebilmesi amaciyla dünyada alternatif eğitim denilince akla gelen bazı öncü alternatif eğitim/okul uygulamalarından bahsetmek gerekir (Ev Okulları (Homeschooling), Montessori Okulları, Summerhill (Özgürlük okulu), Waldorf Okulları).

İlk olarak Ev Okulları (Homeschooling) dünya genelinde bazı ülkelerde yasalarla desteklenen veya bazı ülkelerde yasal bulunmayan bir eğitim sistemidir. 1977 yılında ilk olarak John Caldwell Holt tarafindan uygulanmaya başlanmış ve özellikle Amerika Birleşik Devletlerinde kendine yer bulmuştur. Ev okullarından kasıt "bireylere belli nedenlerden dolayı eğitimin okul yerine evde, aileler tarafından veya ailelerin belirlediği diğer kişiler tarafından çocuklara verilen eğitim" şeklinde ifade edilmektedir (Hadderman, 2002; Şad \& Akdăg, 2010; Taylor \& Petrie, 2000). Ev okulu uygulamaları yapan aileler, çocuklarının eğitiminde birincil ve temel bir rol oynarlar ve tüm sorumluluk ailelere aittir (Aiex, 1994). Bu uygulamaya başlanmasındaki en önemli etkenlerden biri olarak, okullarda kazanılan kötü alışkanlıklar gösterilmektedir. Aynı zamanda ev okullarının uygulanmasındaki en önemli noktalardan biri de kültür aktarımına ciddi oranda olanak sağlamasıdır (Kartal, 2014). Bununla birlikte ev okullarına tamamen karşı çıkan görüşler de bulunmaktadır. Çünkü ev 
okullarında eğitim gören çocukların sosyalleşme fırsatlarının ellerinden alındığı, eğitimi verecek ve çocukları yönlendirecek olan ailelerin zaman zaman yeterli donanıma sahip olmadıkları gibi ciddi eleştiriler mevcuttur (Tösten \& Elçiçek, 2013).

Montessori Okulları Türkiye'de bir kaç okulu bulunan ender alternatif eğitim yaklaşımlarındandır (Öz, 2008) ve felsefesini Dr. Maria Montessori'den alır (Yücesan, Özyürek, 2017). Maria Montessori eğitimi: “öğretmenin bir eylemi değil, öğrencide kendiliğinden gerçekleşen doğal bir işlem olduğundan; birilerinin dinlenmesinin neticesi değil, çocuğun kendi çevresinde yaşadığı tecrübelerin bir sonucu" cümleleriyle ifade eder (Wilbrandt, 2011). Aynı zamanda Montessori yaklaşımı genel olarak okul öncesi eğitime odaklanmıştır. Montessori, tezinde çalıştığı zihinsel engelli öğrencilerin, uygulanan sınavlarda normal zekâlı öğrencilerle aynı başarıyı yakalaması sonucunda, kendi uyguladığı eğitim yönteminin normal zekâlı çocuklara da uygulanabileceğini ve uyarlanabileceğini düşünmüştür (Asher, 2010; Topbaş, 2004). Montessori okulları, öğrencilerin gereksinimlerinin ve bireysel farkl1lıklarının önemsenmesi temeline dayanan bir alternatif okul uygulamasıdır (Memduhoğlu, Mazlum \& Alav, 2015) ve çoklu yaş grupları için (0-3, 36, 6-9, 9-12, 12-14) "hazırlanmış çevreler” kavramı ile açıklanan eğitim yaklaşımını ve çocuğun doğal öğrenme eğilimine dayandıran bir anlayışı ifade eder. (Aydın, 2012). Bununla birlikte Montessori yaklaşımında "eğitim materyalleri” ciddi bir öneme sahiptir (De Jesus, 1987). "Kendi kendine eğitim” fikrini destekleyici özellikler içeren bu materyaller, belirli duyu uyaranlarını izole ettiği için çocuğun ilgisini çekmek ve merakını uyandırma amacıyla tasarlanmıştır (De Jesus, 1987; Durakoğlu, 2010). Montessori eğitimi gören bir çocuğun ilk karşılaştı̆̆ı materyal "günlük yaşam materyalleri/aktiviteleridir". Bu aktiviteler, çocuğun evdeki yaşamına benzeyen günlük aktiviteler olduğundan bu aktivitelerin temel amac1, çocuğun belirli bir beceri kazanarak bağımsızlığını kazanmasına yardım etme, yoğunlaşma ve hareketlerini koordine etme yeteneğini geliştirmektir (Lillard, 2011; Tubaki \& Matsuishi, 2008).

Summerhill okulları (özgürlük okulu), diğer tüm özgür okul örneklerini temsil eden ve özellikle bu amaç ile kurulan ilk ve en ünlü özgür okuldur. 1921'de Birleşik Krallık İngiltere'de Hellerau varoş bölgesinde kurulmuştur. Okulun en temel amacı çocukların kendi ilgilerini keşfetmesidir. Bu okullarda eğitimde otorite, disiplin ve ceza olmazken tam demokrasi ve özyönetim vardır (Gezer,2012). Eğitim bazen 5 bazen 15 yaşında başlar ve genellikle 16 yaşına kadar devam eder (Neill, 2000). Dersler seçmeli olmakla birlikte bu derslere katılım zorunlu değildir. Temel bir not sistemi ve sınavı yoktur. Fakat merkezi sınav 
hazırlığı amacıyla özel çalışmalar yapılır (Gezer, 2012; Summerhill, 2018). Öğrenme kültürünü oluşturan değerler: hoşlandığın işi yap, olmak istediğin kişi ol ve o yolda büyü şeklindedir. Aynı zamanda bu değerler işbirliği temeline dayalıdır (Neill, 2000).

Waldorf okulları ilk olarak 1919 yılında Almanya'nın Stuttgart şehrinde "her nesne, fikir ya da canlı varlığın kendi içinde bir bütün olduğu" fikrine dayanan "Holistik (integral/bütüncül) yaklaşımı benimseyen bir yöntem” olarak ortaya çıkar (Rocha, 2003). Waldorf eğitim yaklaşımında amaç çocukların ihtiyaçlarını anlamak ve integral Holistik zekâyı teşvik etmektir (Nava, 2001). Waldorf eğitimcileri, bu yaklaşımın öğretmenler için yalnızca program ve materyaller değil, yeni bir düşünce biçimi de geliştirme olduğunu vurgular (Rocha, 2003). Bu okulların "bireyselliği destekleyecek şekilde” yapılandırılmaları ve “geleneksel olarak düzenlenmesine” özen gösterilir (Wolcott, 2005). Okul gününün başladığını-bittiğini belirten ya da öğrenme periyotlarını birbirinden ayırmak için çalan ziller yoktur. Öğretmenler program konularının belirlenmesi, uygulama süreci, materyal ve etkinliklerin seçiminde önemli ölçüde özgürdürler (Steiner, 2003). Yani önceki paragraflarda ve bu paragrafta da bahsedildiği gibi Dünyada, özellikle de Amerika Birleşik Devletlerinde eğitimde çeşitli alternatif okullar bulunmakta ve bunların örnekleri giderek artmaktadır. Ancak alternatif eğitim/okul kavramının Türkiye için yeni bir kavram olduğu düşünülmektedir (Memduhoğlu, Mazlum \& Alav, 2015). Türkiye'de alternatif/eğitim ve okullar ile ilgili olan çalışmaların sayısının az olması ve araştırmaların çoğunun doküman incelemesine dayanması bu alan için büyük bir sınırlılıktır. Bu sebepten bu araştırma alternatif eğitim/okul ile ilgili akademisyenlerin görüşlerini bildiren bir çalışma olması sebebiyle oldukça önemlidir. Böylelikle bu araştırmanın amacı "Türkiye'de eğitim fakültelerinde çalışan akademisyenlerin alternatif eğitim/okul uygulamalarına ilişkin görüşlerini belirlemektir" denilebilir.

\section{Yöntem}

$\mathrm{Bu}$ araştırma nitel bir çalışmadır ve veriler yarı yapılandırılmış yazılı görüşme formları aracılı̆̆ı ile toplanmıştır. Ayrıca çalışma grubu, verilerin toplanması ve çözümlenmesi, geçerlik ve güvenirliğe ilişkin bilgiler bu bölümde alt başlık halinde aşağıda verilmiştir.

\section{Çalışma Grubu}

Araştırmanın çalışma grubu, Türkiye'de 36 farklı üniversitenin eğitim fakültelerinde görev yapan toplam 93 akademisyendir. $\mathrm{Bu}$ akademisyenlerin bağlı bulundukları üniversitelere ait bilgilere bakıldığında Abant İzzet Baysal Üniversitesinden 1, Alanya 
Alaaddin Keykubat Üniversitesinden 1, Anadolu Üniversitesinden 1, Balıkesir Üniversitesinden 1, Boğaziçi Üniversitesinden 1, Celal Bayar Üniversitesinden 1, Dokuz Eylül Üniversitesinden 1, Erzincan Üniversitesinden 1, Hacettepe Üniversitesinden 1, Mustafa Kemal Üniversitesinden 1, Pamukkale Üniversitesinden 1, Süleyman Demirel Üniversitesinden 1, Uludağ Üniversitesinden 1, Adnan Menderes Üniversitesinden 2, Afyon Kocatepe Üniversitesinden 2, Ege Üniversitesinden 2, Frrat Üniversitesinden 2, Hakkâri Üniversitesinden 2, Harran üniversitesinden 2, İstanbul Aydın Üniversitesinden 2, Kafkas Üniversitesinden 2, Kahramanmaraş Sütçü İmam Üniversitesinden 2, Manisa Celal Bayar Üniversitesinden 2, Uşak Üniversitesinden 2, Yıldız Teknik Üniversitesinden 2, İnönü Üniversitesinden 3, Kırıkkale Üniversitesinden 3, Trakya Üniversitesinden 3, Bülent Ecevit Üniversitesinden 4, Gaziosmanpaşa Üniversitesinden 4, Giresun üniversitesinden 4, Sakarya Üniversitesinden 4, Çukurova Üniversitesinden 5, Gaziantep Üniversitesinden 5, Muş Alparslan Üniversitesinden 5, Gazi Üniversitesinden 13 akademisyen yer almaktadır. Çalıştığı üniversite bilgisini paylaşmak istemeyen akademisyen sayısı ise 3’tür. Tüm bu akademisyenlerin unvanlarına ait bilgiler ise Tablo1'de yer almaktadır.

Tablo 1. Çalışma Grubundaki Akademisyenlerin Unvan Dağılımları

\begin{tabular}{lcc}
\hline Akademik Unvan & $\begin{array}{c}\text { Frekans } \\
\text { (f) }\end{array}$ & $\begin{array}{c}\text { Yüzdelik } \\
\mathbf{( \% )}\end{array}$ \\
\hline Araştırma Görevlisi & 25 & 26,90 \\
Araştırma Görevlisi Dr. & 4 & 4,30 \\
Öğretim Görevlisi & 3 & 3,20 \\
Öğretim Görevlisi Dr. & 3 & 3,20 \\
Öğretim Üyesi Dr. & 38 & 40,90 \\
Doçent & 13 & 14,00 \\
Profesör & 7 & 7,50 \\
Toplam & 93 & 100,00 \\
\hline
\end{tabular}

Tablo 1'e göre çalışma grubunda 25 Araştırma görevlisi, 4 araştırma görevlisi doktor, 3 Öğretim Görevlisi, 3 Öğretim Görevlisi doktor, 38 doktor öğretim üyesi, 13 Doçent doktor ve 7 Profesör Doktor yer almaktadır. Bu akademisyenlerin hizmet yılına ait bilgiler ise Tablo2'de verilmiştir.

Tablo 2. Çalışma Grubundaki Akademisyenlerin Hizmet Yılı Bilgileri

\begin{tabular}{lcc}
\hline Süre & $\begin{array}{c}\text { Frekans } \\
\text { (f) }\end{array}$ & $\begin{array}{c}\text { Yüzdelik } \\
(\mathbf{\%})\end{array}$ \\
\hline $0-5$ Y11 & 27 & 29,00 \\
6-10 Y1 & 21 & 22,60 \\
11-15 Y11 & 15 & 16,10 \\
16-20 Y11 & 9 & 9,70 \\
20 Y1ldan fazla & 21 & 22,60 \\
Toplam & 93 & 100 \\
\hline
\end{tabular}


Tablo 2'ye göre çalışmaya katılan akademisyenlerin 27'si 0-5 y1l, 21'i 6-10 y1l, 15'i 11-15 yıl, 9'u 16-20 yıldır görev yaparken 21'i ise 20 yıldan uzun süreli hizmet yılına sahiptir.

\section{Verilerin Toplanması ve Çözümlenmesi}

Araştırmanın verileri; araştırmacı tarafından hazırlanan, üzerinde alternatif okul/eğitim ile ilgili soruların yer aldığı yarı yapılandırılmış yazılı görüşme formu aracılığı ile toplanmıştır. Yazılı görüşme formlarıyla bireylerin deneyimlerine, şikâyetlerine, görüşlerine, tutumlarına ilişkin bilgiler toplanmaktadır ve aynı zamanda soruların yarı yapılandırılmış olmasıyla birlikte katılımcı uygun bir esneklik içinde soruları cevaplarken, araştırmacı da konu hakkında daha detaylı bilgiler edinmektedir (Yıldırım \& Şimşek, 2006). Yarı yapılandırılmış yazılı görüşme formu; eğitim fakültesinde çalışan akademisyenlerin Alternatif Eğitim/Okullar konusunda bilgi ve görüşlerini toplayabilmek amaciyla “Alternatif eğitim/okul nedir ve alternatif/eğitim okullar hakkında ne tür bilgilere sahipsiniz? (Evde eğitim, Paideia okulları, Montessori okulları vb.), Alternatif eğitim/okul uygulamalarına ve bu uygulamaların Türkiye'de uygulanabilirliğine ilişkin görüşleriniz nelerdir?, Türkiyede alternatif okul uygulamarına örnekler verebilir misiniz?, Türkiyede faaliyet gösteren alternatif okulların varlığından haberdar mısınız?, Alternatif okulların uygulaması sizce ülkemizde nasıl olabilir?, Çocuğunuzu veya okul çağında olan bir yakınınızı hiç "alternatif okulda" veya "evde" eğitim almasını tavsiye ettiniz mi? Neden?, Sizce ülkemizde alternatif eğitim/okul uygulamalarında ne gibi sorunlar ortaya çıkabilir/çıkmaktadır?” şeklinde yedi adet açık uçlu sorudan oluşmuştur.

Veriler 2017-2018 eğitim öğretim döneminde toplanmıştır. Veriler toplanmadan önce Türkiye'de yer alan her üniversitesinin internet sitesine girerek eğitim fakültesinde görev yapan akademisyenlerin e-posta adreslerine ulaşılmaya çalışılmıştır. Ardından bu e-posta adreslerine bir davet mektubu gönderilmiştir. Davet mektubunda akademisyenlerin “Alternatif Eğitim/Okullar” ile ilgili bir akademik çalışmada yer almak isterlerse eğer linke tıklayarak ve karşılarına çıkan soruları cevaplayarak katkıda bulunmaları istenmiştir. Alternatif Eğitim/Okullar ile ilgili akademisyenlere "Alternatif eğitim/okul uygulamalarının Türkiye'de uygulanabilirliğine ilişkin görüşleriniz nelerdir?”, "Sizce ülkemizde alternatif eğitim/okul uygulamalarında ne gibi sorunlar ortaya çıkabilir/çıkmaktadır?” gibi sorular tek tek sorulmuş ve akademisyenin bu soruları kısa veya uzun bir şekilde süre sınırlaması olmaksızın cevaplamaları istenmiştir. Tüm sorular bittikten sonra akademisyenin karşısına “Gönder düğmesine tıklayarak artık yanıtlarınızı bizimle paylaşabilirsiniz” şeklinde bir uyarı 
çıkarak, son saniye de olsa araştırmaya katılmama/vazgeçme gibi durumu değerlendirmeleri istenmiştir. Böylelikle araştırmaya katılan tüm akademisyenler için gönüllülük esasının dikkate alındığı söylenebilir.

Veriler çözümlenmeden önce, gelen cevaplar incelenmiş ve veri kaybının çok ciddi olduğu katılımcılar elenmiştir. Her bir akademisyene A1,A2,A3 gibi eşsiz bir değer atanmıştır. Verilerin analizinde betimsel analiz tekniği kullanılmıştır. Bu doğrultuda veriler yarı yapılandırılmış yazılı görüşme formundaki sorulara göre ayrıştırılmıştır. Aynı zamanda gerekli yerlerde doğrudan katılımcıların alıntılarına yer verilmiştir. Veriler üç basamak (verileri azaltma, verileri sunma, sonuç çıkarma ve doğrulama) çerçevesinde (Türnüklü, 2000) sunulmuştur (Yıldırım ve Şimşek, 2005). Aynı zamanda veriler sunulurken farklı görüşlere, açıklayıcılık ve uç örnekler dikkate alınmış olup (Carley, 1992'den aktaran Memduhoğlu, 2012; akt. Finney ve Corbett, 2007; Neuendorf, 2002; Ünver, Bümen ve Başbay, 2010) verilerin sunumunda SPSS 20,0 veri analizi yazılım programı kullanılarak, yüzde, frekans vb. betimsel istatistiklerden yararlanılmıştır. Son olarak tüm bu bulgular tümevarım yöntemi 1şı̆̆ında değerlendirilmiştir.

\section{Geçerlik ve Güvenirlik}

Yarı yapılandırılmış sorular hazırlanırken öncelikle alanyazın taranmış ve uzman kişilerin görüşleri dikkate alınmıştır. Yazılı görüşme formundaki soruların dil geçerliliğinin anlaşılabilmesi amacıyla pilot çalışması yapılmıştır. Pilot çalışmasından elde edilen dönütlerle birlikte geçerlik çalışmaları kapsamında iki Eğitim Programı uzmanından ve bir Türkçe Eğitimi uzmanından görüş alınmış ve görüşler doğrultusunda değişiklikler yapılarak form son şeklini almıştır. Bununla birlikte veriler toplandıktan sonra analize dâhil edilen yarı yapılandırılmış yazılı görüşme formlarının 9'u (\%10) rastgele belirlenmiş ve farklı kodlayıcılar (2) tarafından ayrı bir şekilde kodlanmıştır. Bu iki kodlama arasındaki tutarlılık anlamında güvenirliği belirlemek amacıyla Miles \& Huberman'ın (1994) formülü (güvenirlik=uzlaşma sayısı/(uzlaşma sayısı+uzlaşmama sayısı)) kullanılmış, formül sonucu 0,90 olarak çıkmıştır. Bu sonuç tutarlılığın oldukça yüksek olduğunu göstermektedir (Miles \& Huberman, 1994). Araştırmada geçerlik ve güvenirlik anlamında bulguların ortaya konulmasında nesnel davranılmış, nicel-nitel analiz sonuçlarında güvenirlik sağlayabilmek adına sonuçlar ilgili uzmanların görüşlerine sunulmuştur. $\mathrm{Bu}$ sonuçlar kendi aralarında karşılaştırılarak gerekli düzeltmeler yapılmıştır. Böylelikle araştırmacı sürekli olarak kendisini ve süreci eleştirel olarak sorgulayarak analiz ve yorumların gerçeği yansıttığından 
emin olmaya çalışmıştır. Bununla birlikte "araştırma sonuçları ve yapılan çıkarımlara ilişkin kanıtlar" açık ve ayrıntılı bir şekilde ifade edilmiştir.

\section{Bulgular}

\section{Alternatif Eğitim/Okul Hakkında Akademisyenlerin Mevcut Bilgilerine İlişkin Bulgular}

$\mathrm{Bu}$ başlık altında katılımcılara "Alternatif eğitim/okul nedir ve alternatif/eğitim okullar hakkında ne tür bilgilere sahipsiniz?" sorusu sorulmuştur. Bu soruya akademisyenler çok farklı cevaplar vermişlerdir. Akademisyenlerin bir kısmı (29 kişi) bu konu hakkında hiçbir bilgiye sahip olmadığını belirtirken, diğer bir kısmı ise (35 kişi) konuya ilişkin sınırlı kuramsal bilgilerinin olduğunu kabul ederek bazı açıklamaları yapmışlardır. Örnek olarak:

A30: "Doktora ders dönemindeki bir ders kapsamında evde eğitim ve Montessori okulları hakkında araştırma yapmıştım"

A9: "Alternatif eğitim/okul geleneğin dişında eğitimdir"

A88: "Evde eğitiminin Amerika'da sıklıkla kullanıldığını duydum"

A12: "Alternatif eğitim hakkında doktora ders sürecinde hazırladığım bir çalışma kapsamında genel bir çerçevede bilgi sahibiyim"

A7: "Eğitim bilimine giriş derslerimde alternatif eğitimden kısaca söz ediyorum" A87: "Alternatif eğitimin okul öncesi dönemdeki çocukların eğitiminde kullanıldı̆̆ını duydum"

A23: "Romantik yaklaşım ekseninde evde eğitim veren sistemden haberdarım. O da akademik bir kaynaktan ziyade medya vasitasıyla. Çocuğunu okula göndermeyen ünlüler vs."

A4: "Bu tip okullarda çoğunlukla öğrencilerin daha özgür ve hümanist bir eğitim almasının amaçlandığını biliyorum"

Yukarıdaki cevapların haricinde bazı akademisyenlerin konu ile ilgili olarak oldukça detaylı bir bilgi birikimine sahip oldukları görülmektedir. Örnek olarak:

A77: "Alternatif okullar, klasik anlamda örgün eğitim sistemleri içinde yer alan programlara göre daha özgün ve kendine göre bir programı ve yaklaşımı olan okullar ve eğitim sistemleridir"

A46: "Montessori materyallerini fakültemizde Öğretim Teknolojileri ve Materyal Tasarımı (Geliştirme) derslerinde okul öncesi öğretmenliği öğrencilerimizle tasarlayıp örnek materyaller üretmekteyiz" 
A31: "Alternatif eğitiminin, mevcut eğitim/okul dışında olması gerektiği inancıyla gerçekleştirilmeye çalışılan eğitim ve buna ilişkin süreçler olduğunu biliyorum"

A49: "Alternatif eğitimi/okulları eleştirel pedagoji ve eğitim sosyolojisi kapsamında fakültede derslerimde anlatıyorum"

A13: "Alternatif okullar, geleneksel okullara "alternatif" öğrenme ve öğretme ortamlarıdır. Mevcut eğitim sistemine getirilen eleştiriler, duyulan rahatsızlıklar ya da yeni arayışlar sonucu ortaya çıkmıştır"

A4: "Alternatif okullar, devletin örgün eğitim sistemine bağlı olan ve gelir amacı bulunan okullara kıyasla, mevcut eğitim sisteminden farklı eğitim felsefeleri üzerine kurulu olabilen ve farklı eğitim programları kapsamında eğitim veren yerlerdir"

A88: "Yurtdışı kaynaklardan evde eğitim ile ilgili bilgim var. Arkadaşlarımın çocukları Amerika Birleşik Devletlerinde evde eğitim alıyor. Montessori yaklaşımının ise okul öncesi eğitimde kullanıldığını biliyorum. Aynı zamanda İsveç'te Montessori eğitimi veren bir okul ziyareti yaptım”

Ayrıca akademisyenlere “Türkiye'de alternatif eğitim/okul uygulamalarına örnekler verebilir misiniz?" sorusu sorulmuş ve araştırmaya katılan öğretim elemanlarının yarısından fazlası (59) hiçbir örnek verememiştir. Geri kalan akademisyenler ise "Montessori Anaokulu (59), Başka Bir Okul Mümkün Projesi (18), Osmanlı'nın son dönemlerindeki Dadılık/Mürebbiyelik (1), Cumhuriyet Döneminde Bireysel Evde Eğitim Uygulamaları (16), Waldorf Anaokulları (7), Fide Okulları (2), Summer Hill Okulu (1)" şeklinde örnekler vermiştir.

\section{Alternatif Eğitim/Okul Hakkında Akademisyenlerin Görüşlerine İlişkin Bulgular}

$\mathrm{Bu}$ başlık altında katılımcılara "Alternatif eğitim/okul uygulamalarına ilişkin görüşleriniz nelerdir?" sorusu sorulmuştur. Verilen cevaplar incelendiğinde Alternatif Eğitim/Okul hakkında olumlu görüş bildiren akademisyenler mevcuttur. Örnek olarak:

A5: "Denenmesinde toplum için fayda olacağı kanaatindeyim. Bir taraftan toplumun benimsediği ya da zorunlu olduğu eğitim devam ederken bir taraftan da "Daha iyi nasıl eğitim yapılabilir?" sorusuna cevap aranması ve sunulan eğitim hizmetlerinin niteliğinin bu arayışlar neticesinde arttırılması açısından olması gerektiği kanaatindeyim" 
A66: “Alternatif eğitim/okullar, geleneksel okul sistemindeki eksiklikler ve yanlış uygulamaları göz önünde bulundurarak sunulur. Bu çeşitlilik çocukların ihtiyaçlara daha rahat ulaşmasını sağlarken, geleneksel okul sisteminde de olumlu değişiklikler yapılması için iyi örnekler sağlayabilir"”

A79: "Özellikle okul öncesi çocukların hem kas hem zihin gelişimi son derece önemlidir. Alternatif okullar küçük kas gruplarının gelişimini de destekleyerek çocuğa "birey olma, erken yaşta kendi işini görme, sosyalleşme, paylaşım ve yardımlaşma, bilinçlenme ve özel yeteneklerini geliştirme” gibi katkılar sağlayabilir. Yani geleneksel eğitimin yetersiz kaldığı durumlarda alternatif okullar bir çözüm olarak değerlendirilebilir"

A55: "Uzmanlar tarafından verilirse bireysel farklılıkları ortaya çıkarmada faydalı olabilir"

A50: "Alternatif eğitim uygulamalarının öğrenciler ve eğitimciler açısından yararlı olduğunu düşünüyorum. Özellikle TUBİTAK tarafından desteklenen projelerin öğrencilere teorik bilgiler ile gerçek yaşam arasında bağ kurma firsatı sunduğunu düşünüyorum"

A13: "Öğrencinin özel bir durumu (üstün yeteneklilik, otizm vb.) olsun ya da olmasın, bireysel öğrenme hızında farklılık gösteren bazı öğrencileri topluma kazandırmak, toplumdan soyutlamamak, onların ferdi birikimlerinden yararlanmak için alternatif eğitim/okul uygulamaları olmalı, sürekli geliştirilmeli ve devlet tarafından denetlenmelidir”

A21: "Ülkelerin standart eğitimsel hedefleri ve yapısı doğrultusunda alternatif eğitim programlarının yürütülmesinin gerekli olduğunu düşünüyorum”

A90: "Türkiye'de yaygınlaştırılması eğitime katkı sağlayacaktır. Her uygulama gibi doğru olarak uygulanır ve gerekli alt yapı ve koşullar sağlanırsa, iyi sonuçlar alınabileceği kanaatindeyim"

A71: "Evde Eğitim, özellikle evde eğitim almak zorunda kalan kanserli çocukların yararlanması gereken bir hak olduğundan desteklenmesi gerektiğini düşünüyorum"

Akademisyenlerin diğer cevapları incelendiğinde alternatif eğitim/okul hakkında olumsuz görüş bildiren kişiler de mevcuttur. Örnek olarak:

A63: "Fırsat eşitliği ilkesine aykırı olduğu için alternatif okullara/eğitime karşıyım" 
A59: "Alternatif okul/eğitim, öğrencinin akran eğitimi ile kazanabileceği avantajları bazen engelleyebilmektedir (Örn. Evde eğitim). Bu yüzden olumlu yaklaşamıyorum"

A6: “Alternatif okulun/eğitimin benimsediği ilkeler öğrenciyi merkeze aldığı için aslında birçok eğitim modelinde de benimsenen ilkelerdir. Yani alternatif olarak adlandırılmaları da çelişkilidir"

A44: "Bireylerin sosyalleşmesi boyutunu ve içeriğin gerçek hayatla bağlantısını zayıf görüyorum"

A41: "Türkiye için uygun olduğunu düşünmüyorum"

Yukarıda yer alan cevapların haricinde Alternatif Eğitim/Okul Hakkında oldukça temkinli yaklaşan akademisyenler de mevcuttur. Örnek olarak:

A92: "Alternatif okulların kâğıt üzerinde bir felsefi söylemden ibaret kalmak yerine, gerçekte o ülkenin sosyo-kültürel yapısına, eğitime ayrılan bütçeye, öğretmen yetiştirme sistemine olan uygunluğuna göre yaşama geçirilebilme durumlarını değerlendirmek gerekir. Aksi takdirde, eğitimcilerin kendi aralarında tartıştığı ve uygulamaya dönük olmayan ütopik yaklaşımlardan ibaret kalır. Yani bir ülkenin eğitim felsefesi ile bu okulların felsefesinin uyumlu olması gerekir" A19: "Mevcut kitlesel eğitimden memnun olmama, eleştirel pedagoji, farklı arayışlar ve bazen de modadan dolayı insanlar alternatif eğitime yöneliyor. Her eğitim sistemi kendi bünyesinde bu türden farklı uygulamaları bizzat teşvik ederek deneysel çalışmalara zemin hazırlamalıdır. Hangisi daha iyi sonuçlar veriyorsa (yeni arayışlara kapıyı kapatmadan) devlet denetimiyle alternatif eğitim yaygınlaştırmaya çalışmalıdır"

A16: "Alternatif okulların farklı avantajları var. Ancak uygulamada ne kadar iyi uygulandığı bu tür kurumlarda görev yapan eğitimcilerin kendi felsefelerine ne kadar hâkim olduğu konusunda soru işaretlerim var"

A33: “Alternatif okulların Türkiye'de özellikle anaokulu seviyesinde ticari gelir amacıyla kullanıldığını düşünüyorum. Uygulama ve içerik konusunda ciddi sikıntılar mevcut"

A38: "Bazı alternatif eğitim uygulamalarında çeşitli sıkıntıların doğabileceğini düşünüyorum. Bu nedenle artı ve eksilerin göz önünde bulundurulması gerekiyor. Alternatif eğitimin her ülkenin eğitim sistemi içerisinde yer bulması her zaman mümkün değil çünkü köklü değişiklikler gerektiren uygulamalar var” 
A73: “Özellikle bazı açıdan dezavantajlı bireyler(Sağlık veya Sosyal sorunlar) için uygulanabilir olması olumlu fakat ailelerin yeterli bilgi birikimine sahip olmaması bazı durumlar için (Evde eğitim) endişe verici”

\section{Alternatif Eğitim/Okul Uygulamalarının Türkiye'de Uygulanabilirliğine İlişkin Görüşlere Ait Bulgular}

$\mathrm{Bu}$ başlık altında katılımcılara "Alternatif eğitim/okul uygulamalarının Türkiye'de uygulanabilirliğine ilişkin görüşleriniz nelerdir?" sorusu sorulmuştur. Verilen cevaplar incelendiğinde alternatif eğitimin/okulun Türkiye'de uygulanabilirliği hakkında olumlu görüş bildiren akademisyenler mevcuttur. Örnek olarak:

A48: "Devletin verdiği teşvikler ile açılmasını ve uygulanmasını doğru buluyorum"

A13: "Öncelikle iyi bir analiz gereklidir. Kültürümüze, yaşam becerilerine ve eğitim sistemine uyarlandıktan sonra uygulanabilir olduğunu düşünüyorum”

A28: "Uygulanabilir fakat Temel eğitimin yerini almamalıdır"

A60: "MEB programı ile örtüşen uygulamalar mevcut eğitim programına uyarlanarak uygulanabilir"

A39: "Daha çok temel eğitimle sınırlı olarak uygulanabilir"

A20: "Sağlık vb. sorunlu dezavantajlı çocuklar için bir firsat yaratması açısından uygulama imkânları sağlanabilir"

A10: “İhtiyaçlar doğrultusunda belirlenen uygun program, uzman eğitimci ve bilinçlendirilmiş bir aile ve gerekli denetimler ile uygulanabilir olduğunu düşünüyorum"

A18: “Okul öncesine yönelik uygulamalar yapan özel eğitim kurumlarında devlet denetimi altında bireylerin, velilerin ve öğrencilerin uygulanan alternatif eğitim akımı ile ilgili bilgilendirilmesi ile uygulanabilir olduğunu düşünüyorum”

Akademisyenlerin diğer cevapları incelendiğinde alternatif eğitimin/okulun Türkiye'de uygulanabilirliği hakkında olumsuz görüş bildiren kişiler de göze çarpmaktadır. Örnek olarak:

A16: “Türkiye'nin eğitim felsefesine uygun olmadığı için uygulanabilirliğini doğru bulmuyorum."

A6: "Şu anda uygulanamaz çünkü şu an yeterli bilgi birikim, deneyim ve imkân olmadığını düşünüyorum" 
A70: "Yasal bir zemin olmadığı ve Anayasanın 42.maddesine aykırı olduğu için uygulanabilir olduğunu düşünmüyorum"

A7: “Alternatif okullara yönelik bir eğitimin kötü niyetli kişiler tarafindan her türlü suiistimal edilebileceğini düşünüyorum. Bu yüzden alternatif eğitim Türkiye’de uygulanamaz"

A88: "Yasal olarak sınırlamalar var ve bu sınırlamaların olması gerektiğini düşünüyorum. Çünkü bir çocuğun okula çeşitli sebeplerden dolay1 gönderilmemesi(evde eğitim vb.), birçok çocuğu eğitimden mahrum bırakmak olur"

A62: "Sadece eğitim materyalleri anlamında sağlanabilir, diğer anlamlarda uygulanamaz"

A11: "Bazı özel okullarda ticari çıkarlar nitelikten önce geldiği için uygulanamaz. Ayrıca, özel okullar kapsamında bazı okulöncesi kurumlarının reklamlarında alternatif okul uygulamalara dair programları takip ettiklerinin belirtmelerine karşın, gerçek uygulamalarında bu felsefe ile uyumlu olmadıkları, öğretmenlerin yeterli eğitimi almadığı, uygun materyal ve teknik kullanılmadığı ve bunun sadece ticari amaçlı bir söylem olduğunu görmekteyiz. Bu sebeple uygulanabilir bir sistem değil"

A12: "Bazı okullar tarafından güdülen "sınav odaklı" eğitim anlayışı yüzünden Türkiye'de alternatif eğitim uygulamasının zor olduğunu düşünüyorum"

A80: "Veliler, çocuklarının başarısını "salt akademik" olarak algıladıkları sürece alternatif okullar işlevsel olamayacaktır"

A55: "Ülkemizde bu konuda ön yargıların olması nedeniyle pekiyi karşılamadığını gözlemlemekteyim. Ayrıca velilerin alternatif okullar ile ilgili bilgi sahibi olmamasından dolayı bu okulları pek tercih etmedikleri biliyorum. $\mathrm{Bu}$ sebepten uygulanamaz bence”

A2: "Okul seçme ölçütleri içerisinde hala nitelikli üst eğitim kurumlarına öğrenci gönderme kriteri en başta. Dolayısıyla bu okullar bile tanıtımlarında bu yönlerini vurgulamak zorunda kalıyorlar. Zira çocuğunuz güzel şiir okuyacak, spor yapacak, sorumluluk sahibi olacak, yaşamaktan keyif alacak gibi hedefler sönük kalıyor" 
A17: "Yurt dışındaki velilerin yaklaşımı ve kültürü alternatif eğitime uygunken, ülkemizdeki çocuk yetiştirme tarzımızın ve kültürümüzün şimdilik alternatif okullara uygun olmadığını düşünüyorum"

\section{Alternatif Ĕgitim/Okul Uygulamalarının Türkiye'de Ortaya Çıkabilecek Sorunlarına İlişkin Görüşlere Ait Bulgular}

Bu başlık altında katılımcılara "Sizce Türkiye'de alternatif eğitim/okul uygulamalarında ne gibi sorunlar ortaya çıkabilir/çıkmaktadır?" sorusu sorulmuştur. Verilen cevaplar incelendiğinde alternatif eğitim/okul ile ilgili Türkiye'de ortaya çıkabilecek/çıkan sorunlara ait oldukça farklı açılardan görüş bildiren akademisyenler mevcuttur. İlk olarak alternatif eğitimin/okulların çok fazla bilinmemesi ciddi bir sıkıntı olarak ortaya çıkmaktadır. Aynı zamanda yeterli donanım, materyal, yetişmiş eleman eksikliği çekileceğinden dolayı alternatif eğitimin/okulların doğru bir şekilde işlemeyeceğini düşünen görüşler de mevcuttur. Örnek olarak:

A43: "Yetişmiş eleman bulmakta sıkıntı yaşanabilir. Okullarda görev yapan tüm çalışanların uygulanan eğitim anlayışı ile ilgili bilgisi olmaması durumunda disiplin problemleri baş gösterebilir"

A59: "Bu kavramda öncelikle eğitmenlerin eğitimi çok önemli. Sonra toplumun bilinçlendirilmesi geliyor ilk sırada. Anlayıp güvenmediğiniz bir yaklaşıma çocuğunuzu emanet etmezsiniz çünkü”

A25: “Öncelikle alternatif eğitim okullarındaki öğretmenlerin eğitimine dair bilgi ve sertifika seviyesi çok önemli. Şunu unutmamak gerekir ki ülkemizdeki Montessori okullarının çoğunda yurt dışı eğitim sertifikası almış bir öğretmen yok. Bu nedenle önce eğitimin kalitesi sorgulanmalıdır"

A89: "Materyallerin yanlış kullanımı, uygulanacak eğitim modeli felsefesinin tam olarak anlaşılmaması gibi sorunlar yaşanabilir"

A93: "Alternatif okulların benimsedikleri eğitim anlayışını velilere iyi aktarması gerekmektedir, yoksa veliler bu okulları tercih etmeyebilir"

A35: "Alternatif okulun uygulanacak eğitim anlayışını net bir şekilde velilere anlatmaları son derece önemlidir. Bu okulda öğrencilere neler kazandırılacağı açıkça belirtilmelidir. Aksi takdirde okul ile veliler arasında bir çatışma yaşanabilir. Böylelikle velilerin ve toplumun alternatif okullar üzerindeki ön yargıları güçlenebilir" 
A84: "Öğretmenlik mesleğini tercih edenlerin lisans eğitimi sırasında alternatif eğitim alanlarında uzmanlaşmamaları problem yaratabilir"

A7: "Programların uygulanmasında özellikle altyapı ve materyaller konusunda sorunlar çıkabilir. Ayrıca mevcut öğretmen yetiştirme sisteminde alternatif eğitimin uygulanmasına yönelik kapsamlı bir eğitim verilmediği için öğretmen yeterliği açısından sorunlar yaşanabilir"

A32: "Başarı odaklı veliler alternatif okul felsefesini anlamayabilir"

A67: “Alternatif eğitim verilecek grupların yeterlik düzeylerine ve ihtiyaçlarına yönelik öğretim programı eksikliği ciddi bir sorundur"

Yukarıdaki görüşlere ek olarak alternatif eğitimin/okulların Türkiye'nin kültürüne ve eğitim anlayışına uygun olmadığını, var olan sistem ile ciddi uyuşmazlıkları olduğunu düşünen akademisyenler, alternatif eğitimin/okulların Türkiye'de doğru bir şekilde işlemeyeceğini ifade etmişlerdir. Örnek olarak:

A58: “Okulöncesinde böyle bir eğitim alan öğrenci bir üst eğitim kurumunda geleneksel sistemde çok zorlanabilir”

A31: “Alternatif Eğitimin ülke kültürüne, gelenek göreneklerine, çocuk yetiştirme tarzına uygun olmamasından dolayı sorunlar çıkabilir"

A44: "Alternatif bir eğitim anlayışı benimseyen kurumların Milli Eğitim Bakanlığının amaç ve ilkelerine uygun hareket etmemeleri ciddi bir problem yaratabilir"

A90: "Kademeler arası geçişlerde alternatif eğitim/okul uygulamaları sorun çıkartabilir"

A19: “Öğrenciler belli aşamaları geçmek için sınavlara girmek zorundalar ve geleneksel okul sistemi bu sinav sistemine yönelik eğitim veriyor. Sınav sisteminin alternatif okullara yönelik olmaması öğrencilerin kariyerlerinde bir sorun yaratabilir”

A41: “Alternatif okullar eğitim birliğini ortadan kaldırabilir, öğrencilere okul çağında verilmesi gereken bazı manevi değerlerin kazandırılmasında sorunlar yaratabilir"

A23: "Ülkemizde yapılan merkezi sınavlarla ilgili beklentileri alternatif okulları karşılayamama ihtimali bir sorundur" 
A8: "Kültürel olarak bizim kazandırmak istediğimiz değerler yani Türk eğitim sistemine ait değerleri alternatif eğitim alan çocuklara nasıl kazandırılacağ konusu bir sorun yaratabilir"

A12: “Alternatif eğitimi alacak kişilerin mevcut sistem içerisinde iş dünyasına entegre sorunu yaşanabilir."

A88: "Yasal sınırlamaları bir kenara bırakırsak, bir üst seviyede çocuğun gitmek isteyebileceği okul türünün sınavla öğrenci alıyor olması ve daha üst seviyede yükseköğrenime kabulün sınava bağlı olması büyük bir sorun. Alternatif okullarda okuyan çocukların bu kurumlara girmesinde ve okumasında başarısını gösteren çalışmalar olmadıkça bu yönelim sınırlı kalacaktır"

Yukarıdaki görüşlere ek olarak alternatif eğitimin/okulların kötü niyetli bireyler tarafindan kolaylıkla suiistimal edileceğine dair görüşler mevcuttur. Örnek olarak:

A71: “Özellikle yalnızca kız çocuklarının evde okul sistemine yönlendirilmesi bir sorun olabilir”

A37: "Devlet tarafından denetlenmesi sınırlı olacağı için çıkış felsefesine uygun olmayan uygulamalar yapilabilir"

A14: "Rant ortaya çıkabilir. Nicelik arttıralım denilip, niteliğe önem vermeyerek bu ortamların ticarileştirilmeleri sorun olabilir"

A89: "En önemli sorun, alternatif okulları kuranların moda mantığıyla hareket etmeleri; reklam aracı olarak kullanmaları ve alternatif eğitim yaklaşımlarının temel felsefeleri ve ilkelerini anlamamış olmalarıdır"

A47: "Alternatif okulun alternatif olacağız deyip bilim dışı yöntemlere başvurması ciddi bir sıkıntı olabilir"

\section{Tartışma ve Sonuç}

Türkiye'de eğitim fakültelerinde çalışan akademisyenlerin alternatif eğitim/okul uygulamalarına ilişkin görüşlerinin belirlenmeye çalışıldığı bu araştırmanın bulguları doğrultusunda ulaşılabilen ilk sonuç katılımcıların neredeyse üçte birinin alternatif eğitim ve okullar hakkında hiçbir bilgiye sahip olmadığıdır. Bununla birlikte akademisyenlerin bazıları alternatif eğitim ve okullar hakkında sınırlı bilgilerinin olduğunu kabul edip araştırmacı ile görüşlerini paylaşmışlardır. $\mathrm{Bu}$ sonuç literatür ile ciddi benzerlik göstermektedir (Memduhoğlu, Mazlum \& Alav, 2015). Aynı zamanda katılımcıların alternatif eğitim ve okullar ile ilgili edindikleri bilgiler daha çok teorik nitelikte olup, yükseköğretim sırasında 
alınan dersler vasıtasıyla bu bilgiler edinilmiştir. Örnek olarak bir katılımcı (A12) bu konu hakkındaki görüşlerini "doktora ders sürecinde hazırladığım bir çalışma kapsamında genel bir çerçevede alternatif okullar ile ilgili bilgi sahibiyim" şeklinde ifade ederken aynı paralelde diğer bir akademisyen ise "Sadece yüksek lisansta almış olduğum bir dersin içeriği alternatif okullar konusu ile ilgiliydi" cümleleriyle görüşünü ifade etmiştir. Bununla birlikte bazı akademisyenlerin ise alternatif eğitim ve okullar ile ilgili ciddi düzeyde bilgi sahibi olduklarını: "Alternatif okullar, "geleneksel okullara alternatif" öğrenme ve öğretme ortamlarıdır. Mevcut eğitim sistemine getirilen eleştiriler, duyulan rahatsızlıklar ya da yeni arayışlar sonucu ortaya konmuştur (A13)" ve "Alternatif okullar, devletin örgün eğitim sistemine bağlı olan ve gelir amacı bulunan okullara kıyasla, mevcut eğitim sisteminden farklı eğitim felsefeleri üzerine kurulu olabilen ve farklı eğitim programları kapsamında eğitim veren yerlerdir (A4)" cümleleriyle ifade etmişlerdir. Ayrıca akademisyenlerin alternatif eğitim ve okullar hakkındaki mevcut bilgileri sorulduğunda; Türkiye'deki alternatif eğitim/okul uygulamalarına örnek vermeleri istenmiş, katılımcıların yarısı herhangi bir cevap veremezken diğer bir yarısı ise sıklıkla "Montessori” Anaokulundan (59 defa örneklenmiştir) bahsetmiştir. Yani alternatif eğitim/okul hakkında akademisyenlerin mevcut bilgilerine ilişkin bulgulara baktığımızda, bu veriler bize Türkiye' de alternatif eğitimin/okulların teorik olarak bilindiği ve uygulamaları aşamasındaki tanınırlığın (popülerliğin) en çok Montessori Anaokulunda olduğunu göstermiştir. Bu durumun en doğal sebebi ülkemizde özellikle okul öncesi eğitimde Montessori Anaokullarının yaygınlaşmasıdır (Kayılı ve Arı, 2011). Dünyadaki Montessori okulları ile ülkemizdeki Montessori Anaokulları her ne kadar birbirine yüzde yüz benzemese de bu okulların yaygınlaşmasıyla birlikte akabinde yükseköğretimde yapılan çalışmalar (Aslıyürek, 2015; Bayram, 2014; Bayer, 2015; Gülkanat, 2015; Kayılı, 2015; Keçecioğlu, 2015; Mustafayeva; 2016, Özdağ, 2014; Selçuk, 2016; Şeker, 2015; Yücesan, 2016) Montessori Anaokullarının akademik camiada tanınırlığına şüphesiz ciddi manada katkıda bulunmuştur.

Türkiye'de eğitim fakültelerinde çalışan ve araştırmamıza katılan akademisyenlerin alternatif eğitim/okul hakkındaki görüşlerine ait bulgulara bakıldığında genel olarak cevapların olumlu/olumsuz ve temkinli olacak şekilde üç farklı kutup olarak ayrıştığını söyleyebiliriz. Olumlu olduğunu düşünen akademisyenler, geleneksel okul sistemindeki eksiklikler ve yanlış uygulamaları göz önünde bulundurarak alternatif eğitimin/okulların öğrenciler arasındaki bireysel farklılıkları ortaya çıkarmada faydalı olacağını düşünmektedirler. Aynı zamanda çeşitli engel durumları yüzünden (hastalık vb.) "okula 
düzenli olarak gidemeyen ve çeşitli faaliyetlere katılım gösteremeyen öğrencilerin evde eğitim alarak eğitim/öğretim hakkından mahrum kalmaması gerektiği” vurgulamışlardır. Evde eğitimin, çeşitli sağlık sorunu yaşayan öğrencileri eğitim/öğretim alma haklarından mahrum bırakmadığı düşünüldüğünde (Bauman, 2001) bu doğrultuda görüş bildiren akademisyenlerin tespiti oldukça yerindedir. Özellikle günümüzün bilgi ve teknoloji çağ olduğu düşünüldüğünde (Çelen, Mirzeoğlu, Mirzeoğlu, 2010) evde eğitim sırasında bilgisayar ve internetten ciddi bir şekilde faydalanılmakta (Apple, 2004), sanal eğitim ve eokullar sayesinde öğrenciler derslerini sanal ortamlardan rahatlıkla takip edebilmekte (Stevenson, 2007; Şad \& Akdağ, 2010) ve evde eğitimi tercih eden veliler daha rahat bir şekilde bir araya gelerek bilgilerini paylaşabilmektedirler (Basham, Merrifield, Hepburn, 2007).

Alternatif eğitim/okul hakkında olumsuz görüşe sahip olan akademisyenler ise evde eğitim gibi alternatif bir eğitimin, her ne kadar evde eğitimi tercih eden bireylerin sosyalleşmesi amacıyla bir takım etkinlikler uygulansa da, "bireylerin sosyalleşmesi boyutunu” ihmal ettiği ve "içeriğin" gerçek hayatla bağlantısının zayıf olduğunu düşündüklerini belirtmişlerdir. Bu durum diğer akademik çalışmalarla da ortaya konmuştur (Yıldırım vd., 2015). Aynı zamanda özellikle özel okul bünyesinde kendisini gösteren alternatif okulların "fırsat eşitliği ilkesine" aykırı olduğunun altını çizmiş̧lerdir. Tüm bu görüşler ile birlikte bazı akademisyenler ise alternatif eğitime/okullara oldukça temkinli yaklaşmıştır. Bunun en büyük sebebi alternatif okulların kâğı üzerinde bir felsefi söylemden ibaret kalmak yerine, "gerçekte o ülkenin sosyo-kültürel yapısına, eğitime ayrılan bütçeye, öğretmen yetiştirme sistemine ve yasalara olan uygunlukları dâhilinde" devlet desteği ve denetimi ile yaşama geçirilebilme durumlarına göre değerlendirmeleri gerektiğidir.

Akademisyenlerin alternatif eğitim/okul uygulamalarının Türkiye'de uygulanabilirliğine ilişkin görüşlerine bakıldığında ise yine benzer şekilde olumlu ve olumsuz görüşler mevcuttur. Olumlu görüş bildiren akademisyenler; alternatif eğitimin/okulların devlet teşvikiyle ve denetimiyle uygulanmasını, hali hazırda var olan eğitim programları ile örtüşen ve uyarlanabilen bir yapıda olması gerektiğini, ihtiyaçlar doğrultusunda belirlenen uygun program, uzman eğitimci ve bilinçlendirilmiş bir aile ve özelikle ciddi sağlık sorunu yaşayan öğrenciler için uygun olduğu belirtmişlerdir. Olumsuz görüş bildiren akademisyenler ise alternatif eğitimin/okulların "Türkiye'nin eğitim felsefesine uygun olmadığı, yeterli bilgi birikimi ve deneyimine sahip yetişmiş eleman ihtiyacı yaşandığını, kötü niyetli okullar ve bireyler yüzünden ciddi derecede suiistimal edilebileceğini” düşündüklerinden dolayı karşı 
olduklarını belirtmişlerdir. Aynı zamanda bazı özel eğitim kurumlarının sadece ticari çıkarları dikkate almaları; akademisyenlerin zihninde olumsuz bir durum oluşturmaktadır. Bununla birlikte bazı akademisyenler; öğrenci velilerinin, öğrencideki başarı kavramını "salt akademik" olarak algıladıkları sürece Türkiye'de alternatif eğitime/okullara karşı olumsuz bir yaklaşım olacağını ifade etmişlerdir. Okulların amacının öğrencileri sadece akademik anlamda değil, sosyal ve kültürel anlamda değerlere sahip olan bireyler yetiştirmek olduğu düşünüldüğünde (Akbaş, 2007; Aydın, 2010; Balc1, 1988; Dewey, 2008; Milli Eğitim Bakanlığı [MEB], 1992), çeşitli temele dayalı alternatif okulların (Demokratik okullar, Summerhill okulları vb.) “öğrencilerin salt akademik başarılarını yeterince önemsemeyeceği” düşüncesi, öğrenci velileri tarafından ciddi bir sınırlılık olarak algılanabilir.

Son olarak akademisyenlerin alternatif eğitim/okul uygulamalarının Türkiye'de uygulandığında ne tür sorunlar ortaya çıkabileceğine ilişkin görüşlerine bakıldığında çok farklı bakış açılarından yaklaşan akademisyenler mevcuttur. Öncelikli olarak ortak görüş "alternatif eğitim alanda iyi yetişmiş ve yeterli bilgi birikime ve deneyime sahip olan öğretmen ve okul yöneticilerinin bulunmadı̆̆ı" şeklindedir. İyi yetişmiş nitelikli öğretmenlerin eğitim sisteminin genel amaçları açısından önemi düşünüldüğünde (Akyüz, 2001; Aydın, 2007; Duman,1991; Gözütok, 1993; Kavcar, 1987; Köseoğlu, 1994; Şahinkesen, 1989; Tekışık, 1986) en büyük problem "alternatif okul tarafından benimsenen eğitim anlayışının öğrencilere iyi aktarılamaması" olacaktır. Aynı zamanda eğitim öğretimdeki etkinliklerin uygulanışı sırasında farklı problemler de yaşanabilir. Örnek olarak A89 bu durumu en iyi şu cümleler ile ifade etmiştir: "Materyallerin yanlış kullanımı, uygulanacak eğitim modeli felsefesinin tam olarak anlaşılmamasına sebep olabilir”. Diğer bir problem ise velilerin alternatif eğitimi/okulları doğru olarak kavrayamaması, bu konuda yeterli bilgi birikimine sahip olmamaları sebebiyle sıcak bakmamaları ve en önemlisi sadece "salt akademik başarı" odaklı olmalarıdır. Yani bir veli için öncelikli okul/eğitim tercih sebebi "salt akademik başarı" ise bir noktada alternatif okulları tercih etmeme durumu ortaya çıkabilir. Aynı zamanda, araştırmaya katılan akademisyenlere göre, velinin gelenekselci anlayışa sahip olması sebebiyle alternatif eğitimin/okulların tercih edilmesi sürecinde sıkıntılar yaşanabilir. Örnek olarak A31 bu durumu: “Alternatif okul/eğitim ülke kültürüne, gelenek göreneklerine, çocuk yetiştirme tarzlarına uygun olmamasından dolayı sorunlar çıkarabilir" şeklinde ifade ederken diğer bir katılımcı A8 ise bu durumu "Kültürel olarak Türk Eğitim Sistemine ait kazandırmak istenen değerlerin alternatif bir okulda eğitim alan öğrencilere nasıl kazandırılacağı merak konusudur” şeklinde ifade etmiştir. 


\section{Öneriler}

Akademisyenler ile yapılan yazılı görüşmeler sonucu; birçok noktada alternatif okullara/eğitime dair ortada bir bilgi eksikliği olduğundan dolayı, öncelikli olarak alternatif eğitim ve okullar ile ilgili teorik ve deneysel araştırmaların, ilgili bakanlık tarafından akademisyenlere "teşvik edilmesi” gerektiği önerilir. Aynı zamanda özellikle ciddi sağlık problemi yaşayan öğrencilerin eğitim hakkından mahrum kalmamaları için devlet teşviki ile evde eğitime yönelik çalışmaların arttırılması önerilir. Bununla birlikte eğitim fakültelerinde öğretmen yetiştirme alanında "alternatif eğitim/okullara yönelik" sadece "teorik" değil uygulama anlamında da eğitimler verilmesi olumlu olarak karşılanabilir. Son olarak; alternatif eğitimin/okulların ülke kültürüne, gelenek ve göreneklerine, “Türk Milli Eğitiminin Amaçları ve Temel İlkeleri” doğrultusunda uyarlanabilmesi ve geliştirilebilmesi için uygun denetim mekanizmalarının bakanlık içerisinde yer alması gerektiği önerilebilir.

\section{Makalenin Bilimdeki Konumu}

Eğitim Bilimleri / Öğretmen Yetiştirme

\section{Makalenin Bilimdeki Özgünlüğü}

Dünyada, özellikle de Amerika Birleşik Devletlerinde eğitimde çeşitli alternatif okullar bulunmakta ve bunların örnekleri giderek artmaktadır. Ancak alternatif eğitim/okul kavramının Türkiye için yeni bir kavram olduğundan; Türkiye'de alternatif/eğitim ve okullar ile ilgili olan çalışmaların sayısının az olması ve araştırmaların çoğunun doküman incelemesine dayanması bu alan için büyük bir sınırlılıktır. Bu sebepten bu araştırma alternatif eğitim/okul ile ilgili akademisyenlerin görüşlerini bildiren bir çalışma olması sebebiyle oldukça önemlidir.

\section{Kaynaklar}

Adıgüzel, Ö. (2006). Okul dışında farklı bir öğrenme ortamı olarak çocuk müzeleri. Eğitim Bilim Toplum Dergisi, 4(14), 32-41.

Aiex, N. K. (1994). Homeschooling and Socialization of Children. University of Oregon. Bloomington IN.

Akbaş, O. (2007). Türk Milli Eğitim sisteminin duyuşsal amaçlarının (değerlerinin) ilköğretim 8. sınıf öğrencilerinde gerçekleşme derecesinin değerlendirilmesi. Değerler ve Eğitimi Uluslararası Sempozyumu 26-28 Kasım 2004 içinde (ss. 673-695). (Ed: R. Kaymakcan, S. Kenan, H. Hökelekli, Ş. Arslan, M. Zengin). İstanbul: Dem Yayınları. 
Akyüz, Y. (2001). Tarihsel Seyir İçinde Öğretmen Yetiştirmede Kalite, Öğretmen Yetiştirme ve Ĕgitimde Kalite Paneli. Milli Eğitim Bakanlığı, Gazi Üniversitesi, ODTÜ, Hacettepe Üniversitesi, Bilkent Üniversitesi ve Ankara Üniversitesi. Ankara.

Apple, M. (2004). Are We Wasting Money on Computers in Schools? Educational Policy. 18; 513.Online kaynak: 31.03.2008 tarihinde http://epx.sagepub.com/cgi/reprint/18/3/513 erişilmiştir. https://doi.org/10.1177/0895904804265022

Asher, J.J. (2010). TheStory of Maria Montessori, Sky Oaks Productions, Inc., Los Gatos, CA.

Aslıyürek, M. (2015). Montessori eğitiminin 4 - 5 yaş çocukların motor beceri, görsel algl ve bellek, el - göz koordinasyonu ile küçük kas becerilerinin gelişimine etkisinin incelenmesi. Yayınlanmamış yüksek lisans tezi, Fatih Üniversitesi, İstanbul.

Aydın, İ. (2012). Alternatif okullar. Ankara: Pegem A Yayıncılık.

Aydın, İ. P. \& Pehlivan, Z. (2000). Homeschooling: United States Case. Ankara University Journal of Faculty of Educational Sciences, 33(1), 91-97.

Aydın, M. Z. (2010). Okulda değerler eğitimi. Eğitime Bakış, 6(18), 16-19.

Aydın, R. (2007). Türkiye'de eğitimle ilgili yapılan bilimsel toplantılarda ve millî ĕgitim şûralarında ele alınan ögrretmen sorunları ile Millî Eğitim Bakanlı̆̆ı'nın politika ve uygulamalarının değerlendirilmesi (1980 - 2004). Yayınlanmamış Doktora Tezi, Ankara Üniversitesi Eğitim Bilimleri Enstitüsü, Ankara.

Balc1, A. (1988) Etkili okul. Education and Science. 12(70), 21-30.

Balcı, A. (2007). Etkili okul - okul geliştirme, kuram uygulama ve araştırma. Ankara: Pegem A Yayıncilik.

Basham, P., Merrifield, J. \& Hepburn, C.R (2007). Homeschooling from the extreme tothem ain stream. Canada: The Fraser Institute. 03.04.2008 tarihinde http://www.census.gov/population/www/documentation/twps0053.html adresinden erişilmiştir.

Bayer, A. (2015). Montessori yönteminin okul öncesi (36-66 ay) çocuklarının özbakım becerilerine etkisinin incelenmesi. Yayınlanmamış Yüksek lisans tezi, Selçuk Üniversitesi, Konya.

Bayram, B. (2014). Değerler ĕgitiminde Montessori yöntemi. Yayınlanmamış Yüksek lisans tezi, Üsküdar Üniversitesi, İstanbul. 
Bursalığlu, Z. (2005). Okul yönetiminde yeni yapı ve davranış. Ankara, Pegem-A Yayıncilik.

Coeyman, M. (2000). Moreno. 2 pencils at alternative schools. The Chiristian Science Monitor, 92(53), 13.

Çelen, A., Mirzeoğlu, N. \& Mirzeoğlu, A. D. (2010). The effects of the multiple intelligences theory of student's cognitive, affective and psychomotor domains at the physical education lesson.e-Journal of New World Sciences Academy, 5, (4), 251-267.

De Jesus, R. D. (1987). Design guidelines for montessori schools, center for architecture and urban planning research, university of wisconsin, Milwaukee.

Dewey, J. (2008). Okul ve toplum. (Çev: H.A. Başman). Ankara: Pegem Akademi Yayınevi.

Dravor, I. (2009). Eğitimde Değişim Şart, Ayhan Ural (Editör). Ben Bir Okul Uydurdum. Ankara, Pegem-A Yayıncılık.

Duman, T. (1991). Türkiye'de ortaöğretime öğretmen yetiştirme (Tarihi Gelişim). İstanbul: Milli Eğitim Basımevi.

Durakoğlu, A. (2010). Maria Montessori’ye göre çocuğun doğası ve eğitimi, Yayınlanmamış Doktora Tezi, Gazi Üniversitesi, Eğitim Bilimleri Enstitüsü, Ankara.

Finney, S. \& Corbett, M. (2007). ERP implementation: A compilationand analysis of critical success factors. Business Process Management Journal, 13(3), 329-347. https://doi.org/10.1108/14637150710752272

Gezer, İ. (2012). Değişen dünyada ĕgitim. İstanbul: Bilsam Yayınları.

Gözütok, F. D. (1993). Okulda dayak. Ankara: 72 Ofset.

Gülkanat, P. (2015). Okul öncesi öğretmenlerinin Montessori Yöntemi ile gerçekleştirilen eğitim uygulamalarına ilişkin görüşlerinin incelenmesi. Yayınlanmamış Yüksek lisans tezi, Yeditepe Üniversitesi, İstanbul.

Hadderman, M. (2002). Alternative Schools TrendsandIssues. (ERIC Document Reproduction Service No. ED473003).

Kartal, S. E. (2014). Eğitim Paydaşlarının Görüşlerine Göre Alternatif Bir Okul: Ev Okulları. Yayınlanmamış Doktora Tezi. Fırat Üniversitesi Eğitim Yönetimi, Teftişi, Planlaması ve Ekonomisi Ana Bilim Dalı. Elazığ.

Kavcar, C. (1987). Yüksek Öğretmen Okulunun Öğretmen Yetiştirmedeki Yeri, Öğretmen Yetiştiren Yüksek Öğretim Kurumlarının Dünü-Bugünü-Geleceği Sempozyumu. Gazi Üniversitesi Gazi Eğitim, Gazi Mesleki Eğitim, Teknik Eğitim Fakültesi. Ankara. 
Kayılı, G. (2015). Sosyal beceri eğitimi programı ile desteklenmiş Montessori yönteminin anaokulu çocuklarının duyguları anlama ve sosyal problem çözme becerilerine etkisi. Yayınlanmamış Doktora tezi, Selçuk Üniversitesi, Konya.

Keçecioğlu, Ö. (2015). MEB okul öncesi ĕgitim programı ve Montessori yaklaşımına göre eğitim alan 5 yaş çocuklarının sosyal becerilerinin incelenmesi. Yayınlanmamış Yüksek lisans tezi, Marmara Üniversitesi, İstanbul.

Korkmaz H. E. (2005). Montessori Metodu ve Montessori okullarl: Türkiye 'de Montessori okullarının yönetim ve finansman bakımından incelenmesi. Yayınlanmamış Yüksek Lisans Tezi. Marmara Üniversitesi Eğitim Bilimleri Enstitüsü, İstanbul.

Köseoğlu, K. (1994). Illköğretime öğretmen yetiştiren kurumlarda ögretim elemanı yeterliklerinin değerlendirilmesi. Yayımlanmamış yüksek lisans tezi. Ankara Üniversitesi Sosyal Bilimler Enstitüsü, Ankara.

Lillard, P.P. (1973). Montessori, a modern approach. Schocken Books, New York.

Milli Eğitim Bakanlığı [MEB]. (1992). Illköğretim kurumlar yönetmeliği. Ankara: Milli Eğitim Bakanlığı Yayınları.

Memduhoğlu, H. B. (2012). The issue of education supervision in turkey in the views of teachers, administrators, supervisors and lecturers. Educational Sciences: Theory \& Practice, 12(1), 135-156.

Memduhoğlu, H. B., Mazlum M. M. \& Alav Ö. (2015). Views of teachers and academicians about alternative education applications in Turkey, Education and Science, 40(179), 6987. https://doi.org/10.15390/EB.2015.3913

Miles, M, B. \& Huberman, A. M. (1994). Qualitative data analysis: An expanded Sourcebook. (2nd ed). Thousand Oaks, CA: Sage.

Miller, R. (2006). Alternatif eğitim tarihi, (O. Tekinturhan, Çev.). Zil ve Teneffüs Dergisi, 6, 27-31.

Mustafayeva, L. (2016). Montessori eğitim sistemi ve İslam eğitim sisteminin karşılaştırılması. (Yüksek lisans tezi, Uludağ Üniversitesi).

Nalçac1, A. \& Bektaş, F. (2012). Teacher candidates’ perceptions regarding the concept of school. Journal of Ahi Evran University Kırşehir Education Faculty, 13(1), 239-258.

Nava, R.G. (2001). Holistic education pedagogy of universal love. Educational Renewal, Brandon, USA.

Neill, A. S. (2000). Özgürlük okulu (1.bs.), (N. Şarman, Çev.). İstanbul: Payel Yayınevi.

Neuendorf, K. A. (2002). The content analysis, guidebook. California: Sage Publications. 
Öz, M. (2008). Amerika'da Alternatif Bir Eğitim Modeli Olarak Kişi Merkezli Eğitim. Yayınlanmamış Yüksek Lisans Tezi. Beykent Üniversitesi Sosyal Bilimler Enstitüsü, İstanbul.

Özdağ, S. A. (2014). Montessori metodu'nun eğitim mekânlarına yansıması üzerine kavramsal bir analiz. Yayınlanmamış Yüksek lisans tezi, Karadeniz Teknik Üniversitesi, Trabzon.

Rocha, D.L.S. (2003). Schools where children matter exploring educational alternatives. Educational Renewal, Brandon, USA.

Selçuk, K.S. (2016). Montessori yönteminin anaokulu çocuklarının büyük kas becerilerine etkisinin incelenmesi. Yayınlanmamış Yüksek lisans tezi, Necmettin Erbakan Üniversitesi, Konya.

Steiner, R. (2003). What is waldorf education?, three lectures by Rudolf Steiner. Introduction by Stephen Keith Sagarin, PublishedBySteinerBooks, Great Barrington, MA.

Stevenson, K. R. (2007). Educational Trends Shaping School Planning and Design: 2007 .National Clearing house for Educational Facilities. 30.05.2008 tarihinde http://www.edfacilities.org/pubs/trends2007.pdf adresinden erişilmiştir.

Summerhill (2018). Summerhill - An overview. 23 Ocak 2018 tarihinde http://www.summerhillschool.co.uk/an-overview.php adresinden erişildi.

Şad, S. N. \& Akdağ, M. (2010). Evde eğitim. Milli Ĕ̆itim, 39(188), 19-29.

Şahinkesen, A. (1989). Ortaöğretim kurumlarında görevli öğretmenlerin süreçler yönünden değerlendirilmesi. Ankara Üniversitesi Eğitim Bilimleri Fakültesi Dergisi, 22 (1), 101133.

Şeker, K. N. (2015). Kırsal bölgede okul öncesi eğitime devam eden 5 yaş çocukları ile Montessori eğitimi alan 5 yaş çocukların motor becerilerinin karşılaştırılması. Yayınlanmamış Yüksek lisans tezi, Selçuk Üniversitesi, Konya.

Taylor, L. A. \& Petrie, A. J. (2000). Home education regulations in Europe and recent U.K. $\begin{array}{lllll}\text { Research. PeabodyJournal of } & \text { Education, } & 75 & \text { (1\&2), } & 49-70 .\end{array}$ https://doi.org/10.1080/0161956X.2000.9681935

Tekışık, H. H. (1986). Türkiye'de Öğretmenlik Mesleği ve Sorunları, Çağdaş Gelişmeler Işığıında Türkiye'de Eğitim Fakültelerinin Yeri ve Rolü Uluslararası Sempozyumu. Hacettepe Üniversitesi Eğitim Fakültesi. Ankara.

Topbaş, E. (2004). Montessori yöntemi ile çocuk eğitimi, Tekağaç Eylül Yayınları, İstanbul. 
Tösten, R. \& Elçiçek, Z. (2013). Home Schools within the Scope of Alternative Schools. Journal of Ziya Gökalp Faculty of Education, 20 (2013) 37-49.

Tubaki, M. \& Matsuishi, T. (2008). On the pedagogical theory of Maria Montessori, Journal of Disability and Medico-Pedagogy, 18, 1-4.

Türnüklü, A. (2000). Eğitim bilim araştırmalarında etkin olarak kullanılabilecek nitel araştırma tekniği: Görüşme. Kuram ve Uygulamada Ĕ̆itim Yönetimi, 24, 543-559.

Ünver, G.,Bümen, N. T. \& Başbay, M. (2010). Faculty members’ perspectives towards secondary teacher education graduate courses at Ege University. Education and Science, 35(155), 63-77.

WEB, (2019).

http://www.montessoriegitimi.org/yerarti/joomla/index.php?page=shop.browse\&catego ry_id=18\&option=com_virtuemart\&Itemid=26 adresinden 1 Mayıs 2019 tarihinde erişilmiştir.

Wilbrandt, E. Ç. (2011). Maria Montessori yöntemiyle çocuk eğitimi sanatı, 2. Baskı, Sistem Yayıncılık, İstanbul.

Wolcott, J.S. (2008). Waldorf egitimi: ruhun egitimi. M. Hesapçıoglu, E. Korkmaz, S. Dündar, B.G. Morhayim, M. Çavus (Ed.), 1. Alternatif Egitim Sempozyumu Bildiri Kitab1.

Yıldırım, A. \& Şimşek, H. (2006). Sosyal bilimlerde nitel araştırma yöntemleri.(6. baskı) Ankara: Seçkin Yayıncılık.

Yıldırım N.,Talas S.,Yazıcı L.,Nural H.,Çelebi İ.,Çetin K.,Acet Ö.,Pelitli Ü.,Çaylak M. (2015). Evde Eğitim Alan Öğrencilerin Eğitim Süreçlerinin Değerlendirilmesi Tokat İli Örneği. Eğitim Kuram ve Uygulama Araştırmalarl Dergisi. 1,33-52.

Yücesan, Y. (2016). Montessori eğitiminin okul öncesi dönem çocukların problem çözme becerileri ve problem davranışları üzerine etkisinin incelenmesi. Yayınlanmamış Yüksek lisans tezi, Karabük Üniversitesi, Karabük.

Yücesan, Y. \& Özyürek, A. (2017). Montessori Eğitimi Alan Ve Almayan Okul Öncesi Dönem Çocukların Problem Davranışlarının İncelenmesi. LAÜ Sosyal Bilimler Dergisi (VIII-II), 215-226. 


\section{Summary}

\section{Statement of Problem}

School is defined as "The educational institution where all kinds of education and teaching are realized as a group; the information, skills and habits are taught and gained regularly according to certain purposes”.

When it is thought that the schools have social, political, and economic duties; the main objective of the schools is to erase negative social, political, and economic effects of the environment; at the same time, to reinforce the positive social, political, and economic effects of it.

Because of the arising criticism towards these duties of school stating "in addition to the education in parallel with both individual and social needs, it makes people acquire bad habits that society and families do not desire”, people have been looking for different alternatives from time to time. This situation has resulted in the emergence of the concepts such as “alternative education/alternative school” in process of time.

There are various alternative schools in the world, especially in USA and the numbers of the examples are increasing day by day. However, it is thought that alternative education/schools is a new concept for Turkey. It is a major limitation for this area that in Turkey, the number of studies on alternative education/schools is quite few in number and most of these studies are based on documentation analysis. As a result, the present study has a great importance since it presents the related academics' views on alternative education/school. The aim of this research is to "identify the views of academics working at education faculties in Turkey on alternative education/school applications”.

\section{Method}

This is a qualitative research and the data were collected through semi-structured interview forms. Participants of the study are a total of 93 academics who are working in 36 different university’s education faculties in Turkey.

The data was collected through the semi-structured interview form prepared by the researcher and consisting of questions on alternative school/education. The data was collected in 2017-2018 academic year. Before the data were analyzed, the responses were examined and participants whose data loss was too severe were eliminated. Each academic had a unique value like A1, A2, and A3. Descriptive data analysis was utilized to analyze the data. In this direction, the data were separated according to the questions in the semi-structured interview form. 


\section{Findings}

In this section, the academics were asked such questions "What is alternative education/school? and what do you know about alternative education/schools?”. As an answer to the questions, the academics answered variably. While some of them stated that they had no idea about that topic (29 participants), the others accepted that they had limited theoretical information about the topic and made some explanations (35 participants). Apart from the above answers, some academicians seem to have a very detailed knowledge of the subject. In addition to these, the academics were asked the question: "Could you give an example of alternative education/school applications in Turkey?”, and more than half of the academics participated in the study (59) could not give any examples.

"What are your views on the practicality of alternative education / schools applications in Turkey?” was asked to the participants. Analyzing the answers given, there were academics who expressed positive opinions about the applicability of alternative education / school in Turkey. Considering other answers of academics, the participants indicating a negative opinion on the applicability of alternative education / school in Turkey also stood out.

The analysis of the answers showed that there were academics who expressed quite various views on the problems which can emerge related to alternative education / schools in Turkey. First, it is a big problem that alternative education / schools are not known much. At the same time, there are opinions suggest that alternative education / schools will not work properly because of lack of adequate equipment, materials, and trained staffs. In addition to these, the academics who thought alternative education/schools did not fit to the understanding of Turkish culture and education, there were serious conflicts with the current system, the academics also stated that alternative education/schools do not work properly in Turkey.

\section{Discussion and Conclusion}

The initial result in accordance with the findings of this study that aimed to determine the views of academics working in faculties of education in Turkey on alternative education/school showed that nearly one third of all the participants do not have any information about alternative education and schools. In addition to this, some of the academics stated that they had limited information about alternative education and schools and shared their own views. 
Academicians who had negative views about alternative education / school had stated that alternative education such as home education neglected "socialization dimension of individuals" and thought that the "content" had a weak connection with the real life. At the same time, they underlined the fact that alternative schools, especially those that appear in private schools were against "the principle of equal opportunity".

At the end of the interviews with academics; as there is a deficiency of information about alternative education/schools at several points, it can initially be suggested that the theoretical and experimental research on alternative education and schools should be “encouraged" by the related ministry. 